\title{
Familial nonmedullary thyroid carcinoma
}

INSERM

\section{Source}

INSERM. (1999). Orphanet: an online rare disease and orphan drug data base. Familial nonmedullary thyroid carcinoma. ORPHA:319494

Familial nonmedullary thyroid carcinoma ( $\mathrm{fNMTC}$ ) is a rare non-syndromic form of thyroid cancer characterized by occurrence of thyroid carcinoma (TC) as the primary feature in a familial setting. 